\title{
Article
}

\section{The key to employability: developing a practical model of graduate employability}

Dacre Pool, Lorraine and Sewell, Peter John

Available at https://clok.uclan.ac.uk/8347/

Dacre Pool, Lorraine orcid iconORCID: 0000-0003-2049-8670 and Sewell, Peter John (2007) The key to employability: developing a practical model of graduate employability. Education + Training, 49 (4). pp. 277-289. ISSN 00400912

It is advisable to refer to the publisher's version if you intend to cite from the work. http://dx.doi.org/10.1108/00400910710754435

For more information about UCLan's research in this area go to

http://www.uclan.ac.uk/researchgroups/ and search for <name of research Group>.

For information about Research generally at UCLan please go to http://www.uclan.ac.uk/research/

All outputs in CLoK are protected by Intellectual Property Rights law, including Copyright law. Copyright, IPR and Moral Rights for the works on this site are retained by the individual authors and/or other copyright owners. Terms and conditions for use of this material are defined in the policies page.

\section{CLoK}

Central Lancashire online Knowledge www.clok.uclan.ac.uk

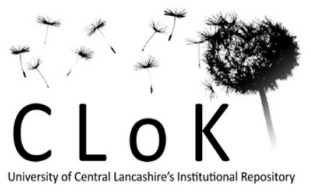




\title{
The Key to Employability
}

\section{Developing a practical model of graduate employability}

\author{
Lorraine Dacre Pool and Peter Sewell \\ Centre for Employability, \\ University of Central Lancashire, Preston, UK.
}

\begin{abstract}
Purpose

This paper introduces a straightforward, practical model of employability that will allow the concept to be explained easily and that can be used as a framework for working with students to develop their employability.
\end{abstract}

\section{Design/methodology/approach}

The model was developed from existing research into employability issues and the experience of the authors. The various elements of employability included in the model are discussed and their inclusion justified on the basis of existing research.

\section{$\underline{\text { Research limitations }}$}

The relationships between and the interaction of the elements within the model remain theoretical. Further research to test the model is planned and will be reported on at a later date.

\section{Practical implications}

The model can be used to explain the concept of employability to those new to the subject, and particularly to students and their parents. It will be a useful tool for lecturers, personal tutors, careers advisors and any other practitioners involved in 
employability activities. It will also be used to develop a measurement tool for employability.

\section{Originality/value}

This paper seeks to fill the gap between in depth, scholarly and complex articles or books about employability and very simple descriptive articles. It sets out for the first time exactly what is meant by employability, in clear and simple terms, and the model suggests directions for interaction between the various elements. It will be of value to anybody with an interest in employability issues.

Keywords: employability model, career development, higher education

Paper type: Research paper 


\section{Introduction}

In recent years a number of models of employability have been proposed. Whilst these models go some way towards capturing the meaning of this elusive concept of employability, they are either too elaborate to be practically useable or too simple to do justice to this multifaceted issue. For many people employability is simply about getting a job and the term is increasingly used carelessly and interchangeably with 'enterprise' which in turn is confused with 'entrepreneurship'. The aim of this paper is to present a practical, coherent model, that is firmly based on existing research findings in employability and on the various individual elements that make up the framework. Employability is an issue of concern in many areas of the economy, but in this context the focus is on students and graduates in UK Higher Education.

\section{Employability in Higher Education}

Current interpretations of employability range from the use of simple measures, such as whether or not a graduate has secured a job (using graduate first destinations surveys), to in depth scholarly books on the subject. If employability is measured in the simplistic terms of whether or not a graduate has managed to secure a job within six months of graduating, it only provides a very vague and imprecise indication of what the student has gained. Questions need to be asked about whether or not the graduate is using the skills, knowledge and understanding gained in their degree studies in a 'graduate level job', which in turn opens up a whole new debate about what exactly a 'graduate level job' entails. There is so much more to employability than gaining employment and first destination statistics do not take into account the fact that some graduates may have taken lower level jobs in order to deal with financial pressures, particularly after incurring debts through their studies. 
Hillage \& Pollard (1998) suggest that:

"In simple terms, employability is about being capable of getting and keeping fulfilling work. More comprehensively employability is the capability to move self-sufficiently within the labour market to realise potential through sustainable employment." (p 2).

They propose employability consists of four main elements. The first of these, a person's 'employability assets' consists of their knowledge, skills and attitudes. The second, 'deployment' includes career management skills, including job search skills. Thirdly, 'presentation' is concerned with 'job getting skills', for example CV writing, work experience and interview techniques. Finally, Hillage \& Pollard also make the important point that for a person to be able to make the most of their 'employability assets' a lot depends on their personal circumstances (for example family responsibilities) and external factors (for example the current level of opportunity within the labour market).

Bennett, Dunne \& Carré (1999) proposed a model of course provision in higher education which included five elements: disciplinary content knowledge, disciplinary skills, workplace awareness, workplace experience and generic skills. This model goes some way towards including all the necessary elements to ensure a graduate achieves an optimum level of employability but is still missing some vital elements.

The USEM account of employability (Yorke \& Knight, 2004, Knight \& Yorke, 2004) is probably the most well known and respected model in this field. USEM is an acronym for four inter-related components of employability:

- Understanding 
- Skills

- Efficacy beliefs

- Metacognition

The authors suggest that behind the USEM model is:

"an attempt to put thinking about employability on a more scientific basis, partly because of the need to appeal to academic staff on their own terms by referring to research evidence and theory..." (Knight \& Yorke, 2004, p 37).

The USEM model forms part of a large body of research based, scholarly work on employability. However, this strength could also be perceived as a weakness in that it does not assist in explaining to non-experts in the field, particularly the students themselves and their parents, exactly what is meant by employability.

The Centre for Employability (CfE) at the University of Central Lancashire (UCLan) in the UK has been developing practical solutions to enhance the prospects of students and graduates for over 10 years. As a consequence of the careers service origins of this unit, the main theoretical model which has underpinned this work has been the DOTS model (Law \& Watts 1977), which consists of:

"planned experiences designed to facilitate the development of:

Decision learning - decision making skills

Opportunity awareness - knowing what work opportunities exist and what their requirements are

Transition learning - including job searching and self presenting skills 
Self awareness - in terms of interests, abilities, values, etc." (Watts, 2006, p 9/10).

The value of this model lies in its simplicity, as it allows individuals to organise a great deal of the complexity of career development learning into a manageable framework. However, the model has recently attracted some criticism. McCash (2006) argues that the model is over reliant on a mechanistic matching of person and environment and therefore underplays other critical issues such as social and political contexts. He also points out that there is an implication that failure to secure a 'self-fulfilling' occupation can be presented, or experienced, as the fault of the unsuccessful individual. These criticisms overlook the fact that the elegant simplicity of the DOTS model is precisely why it has proved so enduring and popular. They also seem to suggest that students introduced to basic concepts of career development through DOTS, would be incapable of developing and learning about more sophisticated analyses through this simple introductory structure.

The concerns raised in the CfE about DOTS in relation to employability are different. For some time, it has become evident that the model has shortcomings when it is applied beyond careers education to the broader concept of employability. An early effort to capture the CfE definition of employability was reported in Hinchcliffe (2001):

"Reflecting the range of views we see Peter Sewell of the CLASS Faculty Centre for Employability making the career development case and defining employability as: Having a set of skills, knowledge and personal attributes that make a person more likely to secure, and be successful in their chosen occupation." (p 8). 
The most recent articulation of this, which incorporates an important additional new element of 'satisfaction', stems from the recognition that from an individual's perspective a person may be successful in their chosen occupation but not necessarily satisfied.

"Employability is having a set of skills, knowledge, understanding and personal attributes that make a person more likely to choose and secure occupations in which they can be satisfied and successful."

This definition has been used as a starting point from which to develop a new theoretical and practical framework for employability called 'The Key to Employability' model.

It could be argued that in addition to drawing together the essential conceptual issues that underpin an understanding of the concept of employability, this model also provides a clear, visual answer to the simple question of what employability is. This has the benefit of not only articulating the concept of employability in a theoretically rigorous manner but doing so in a way that is easily accessible both to practitioners and students. The framework also opens up new opportunities for the development of assessment tools and research into the impact of various employability interventions.

\section{The Model}

The design of the model reflects an assertion that each component is absolutely essential and one missing element will considerably reduce a graduate's employability. A degree of overlap between some of the components is 
acknowledged and this is reflected in the visual presentation of the model. However it is not suggested that these are the only areas of overlap as this occurs at various points. For example, in addition to work experience being a valuable part of career development learning, it may in some cases directly inform subject learning relevant to the degree course being studied.

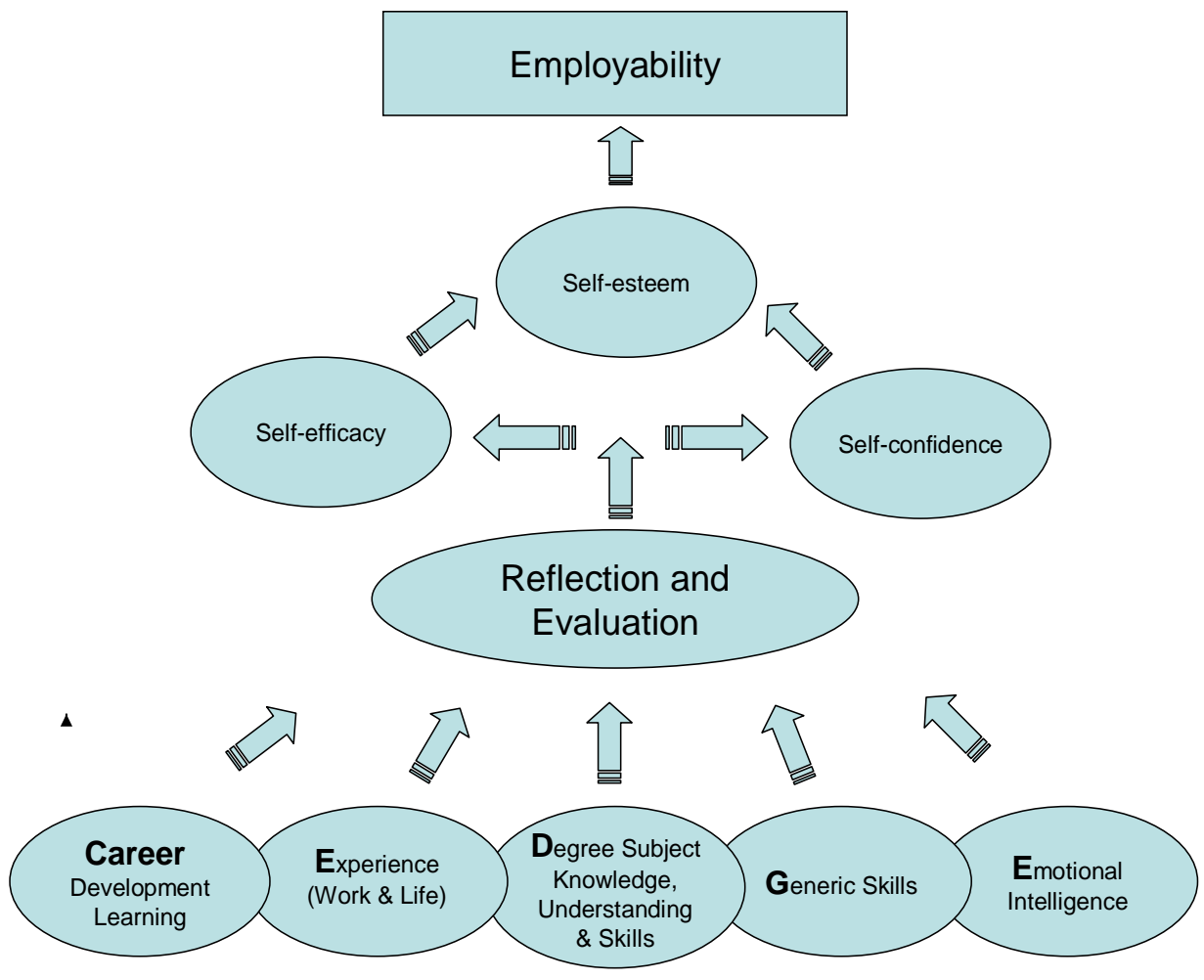

Figure 1. The essential components of employability

The model depicted in Figure 1 above illustrates the essential components of employability and also suggests the direction of interaction between the various elements. The mnemonic CareerEDGE is used as an aid to remember the five components on the lower tier of the model. It is suggested that providing students with opportunities for them to access and develop everything on this lower tier and essentially, for reflecting on and evaluating these experiences, will result in 
development of higher levels of self-efficacy, self-confidence and self-esteem - the crucial links to employability.

The original model detailed in Figure 1 clearly shows all the components and suggests the direction of interaction. From this, Figure 2 evolved, with the metaphorical image of a 'key'. This pictorial version of the model is a useful, practical way of explaining the concept of employability and indicates that it is the 'key' to choosing and securing occupations in which the graduate has the opportunity to achieve satisfaction and success.

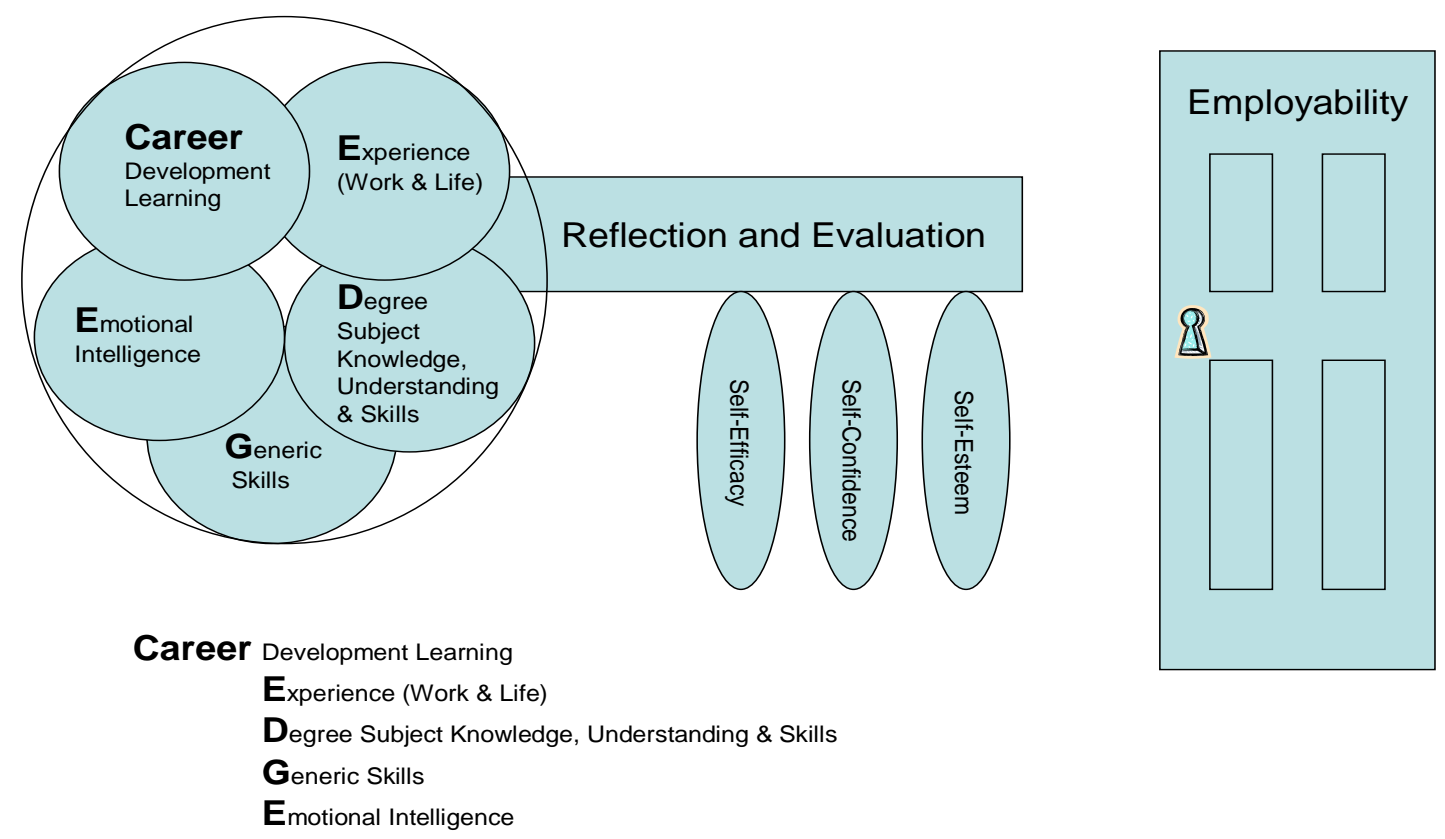

CareerEDGE - The Key to Employability

Figure 2. A metaphorical model of employability

The Model Components

Degree subject knowledge, understanding and skills. 
This has to be a central concept in the model. The motivator to enter Higher Education is generally perceived to be to study a specific discipline in depth, to gain a degree, get a higher qualification and thus get a good or better job and it still remains the case that the better qualified have far greater employment opportunities (Johnes, 2006). Graduate Prospects (2005/6, p 17) identified two-thirds of graduate vacancies as open to graduates of any discipline, which implies that for the remaining third, subject specific knowledge, understanding and skills are still of vital importance. It is essential to recognise that employers will judge graduates on the basis of how successfully they have completed their degree course, i.e. their degree classification, perhaps because this is often the sole measure available to them. This tends to be the case whether they are entering an occupation with direct relevance to their degree or not and as such there is a need to recognise the central importance of this particular element of graduate employability. However, even though the subject specific knowledge, understanding and skills are still extremely important in many cases, these alone are unlikely to secure a graduate occupations in which they can be satisfied and successful.

\section{Generic skills}

There has been considerable debate in the literature about the terminology for generic skills, which may also be referred to as 'core skills', 'key skills' or 'transferable skills'. The term 'generic skills' has been used for the purpose of this model and is used:

"to represent the skills which can support study in any discipline, and which can potentially be transferred to a range of contexts, in higher education or the workplace." (Bennett, Dunne \& Carré, 1999 p 76). 
In Yorke \& Knight's (2002, p. 2) paper, they discuss some of the research into the value placed by employers on generic skills in graduates and interpret the message from employers as:

"Give us a bright and engaged graduate, and we will build specific expertise for this organisation on top of that."

Employers want graduates with relevant subject specific skills, knowledge and understanding, but in addition to this are looking for well developed generic skills in a number of areas (Harvey, Moon, Geall \& Bower, 1997). A considerable amount of work has been published which lists the many generic or transferable skills that employers are looking for. The Pedagogy for Employability Group (2004, p 5) provides a list derived from research carried out over the last twenty-five years and suggests that employers expect to find that the following generic skills have been developed in graduates:

- imagination/creativity

- adaptability/flexibility

- willingness to learn

- independent working/autonomy

- working in a team

- ability to manage others

- ability to work under pressure

- good oral communication

- communication in writing for varied purposes/audiences

- numeracy 
- attention to detail

- time management

- assumption of responsibility and for making decisions

- planning, coordinating and organising ability

- ability to use new technologies (not included in the list above but mentioned in many others and an important element).

There is also the need to mention enterprise and entrepreneurship skills, which are often discussed in the employability literature. It is likely to be the case that an enterprising graduate would be valued in any organisation, either profit-making, nonprofit making, large or small. For the purpose of this model, it is suggested that a graduate who could be described as enterprising would be imaginative, creative, adaptable, a willing learner; in fact they would have most of the skills already listed under the 'generic' category. Entrepreneurial skills, on the other hand, may be a valuable addition that some graduates will want to acquire, but not all. Not everybody wants to set up their own profitable business. As entrepreneurial skills are not considered an essential element in the model, they have not been included.

\section{Emotional Intelligence}

Goleman (1998, p. 4) provides strong support for the inclusion of emotional intelligence in any model of employability when he says:

"In a time with no guarantees of job security, when the very concept of a "job" is rapidly being replaced by "portable skills", these are prime qualities that make and keep us employable. Talked about loosely for decades under a 
variety of names, from "character" and "personality" to "soft skills" and "competence", there is at last a more precise understanding of these human talents, and a new name for them: emotional intelligence."

Moynagh \& Worsley (2005) suggest that in the future knowledge based economy, emotional intelligence will become even more important with the predicted expansion of customer-facing jobs in which human interaction plays a central part.

Emotional intelligence has been defined as:

"the capacity to reason about emotions, and of emotions to enhance thinking. It includes the abilities to accurately perceive emotions, to access and generate emotions so as to assist thought, to understand emotions and emotional knowledge, and to reflectively regulate emotions so as to promote emotional and intellectual growth." (Mayer, Salovey \& Caruso, 2004, p 197).

In more simple terms, Goleman (1998, p. 317) who has done much to make emotional intelligence accessible to a wide audience, defines it as:

"the capacity for recognising our own feelings and those of others, for motivating ourselves, and for managing emotions well in ourselves and in our relationships."

As with all the components in the model, in order to achieve their true employability potential, a graduate will need to have well developed emotional intelligence competencies. Yorke \& Knight (2002) list emotional intelligence as one aspect of employability under their personal qualities section but it could be suggested that it in fact subsumes many of the other personal qualities listed and some of the process 
skills listed too. As such it deserves a much higher profile. Research has shown that people with high levels of emotional intelligence motivate themselves and others to achieve more. They also enjoy more career success, build stronger personal relationships and enjoy better health than those with low levels of emotional intelligence (Cooper, 1997). Jaeger (2003, p. 634) demonstrated that emotional intelligence can be improved through teaching and learning in a higher educational setting and is positively correlated with academic achievement. She suggests that:

\footnotetext{
"Enhancing emotional intelligence is a desirable outcome for students, employees and employers."
}

Tucker, Sojka, Barone and McCarthy (2000, p. 336) state that:

\begin{abstract}
"As educators, we want our students to graduate with a solid foundation in the knowledge and skills they will need to be productive managers and effective leaders. By implementing emotional intelligence theory and exercises, faculty will help students become well-rounded graduates."
\end{abstract}

They also give suggestions as to how emotional intelligence can be incorporated into the curriculum.

As emotional intelligence is not fixed genetically, nor does it only develop during early childhood (Goleman, 1998, p. 7), then it seems to be something people can learn, which would suggest that this is something that Higher Education Institutions (HEI) can successfully teach. The issue of emotional intelligence, or emotional literacy as it is often described, has been taken on board by many primary and secondary schools keen to improve these skills for their pupils. If the large amount of research looking at the academic and life success of people with high levels of emotional 
intelligence is taken into account (see Qualter, Whiteley \& Gardner, 2007 for review), it is difficult to see how any model of graduate employability would be complete without its inclusion.

\section{Career Development Learning}

For a graduate to stand the best chance of securing occupations in which they can be satisfied and successful, it is essential that they receive some education in career development learning.

According to Watts (2006) career development learning has not always been as strongly represented in HEI employability strategies as it should have been. However he does suggest that there is evidence that this is changing. Career development learning, as based on the DOTS model (Law \& Watts, 1977) should include activities that help students to become more self-aware, to enable them to give real consideration to the things that they enjoy doing, are interested in, motivate them and suit their personalities. They also need to learn how best to research the job markets to see what opportunities are available to them, how to present themselves effectively to prospective employers and how to make considered decisions about their careers. As stated by Foster (2006, p. 5):

"There is little to be gained in developing employability if, at the end of the day, a student cannot identify a market in which to advertise their newly developed employability."

Importantly, after acquiring so much knowledge, understanding and skill at university, they will need help and guidance in how best to explain to potential employers about 
their achievements and how they will be of benefit to them, in application forms, CVs and interview activities.

\section{Experience - Work and Life}

So much research points to work experience as being something that prospective employers value greatly in graduates. Some of the key findings of the Work Experience Group (2002), appointed by the government to look at work experience opportunities in Higher Education, were as follows:

- "With guidance, students of all ages can learn from their experiences in the world of work to develop their key competences and skills and enhance their employability.

- Employers value people who have undertaken work experience, been able to reflect upon that experience and then go on to articulate and apply what they have learnt.

- Partnerships between employers and Education are valuable in promoting work-related learning and in improving the quality and quantity of such experiences." ( $p$ 4)

According to the Pedagogy for Employability Group (2004), it is widely agreed that graduates with work experience are more likely to secure employment than graduates without. It is also important to consider the wider life experiences that many students, particularly mature students, bring with them into Higher Education. There is a need therefore for students to be given this information and provided with guidance as to how their life experience and work-related experience, either 
arranged as part of a course, carried out on a voluntary basis or gained through parttime work, can be used to enhance their levels of employability.

\section{Reflection and Evaluation}

Providing students with the opportunities to gain the necessary skills, knowledge, understanding and attributes is obviously important, but so too is providing opportunities for reflection on and evaluation of the learning experiences that have already taken place. Without these opportunities, a student is unlikely to give full consideration to how far they have come in developing their employability and what they may need to do in order to develop it further. Moon (2004) provides a full discussion of the crucial role of reflection in the context of employability. This element of reflection and evaluation is also the key to development of the 'three Ss' discussed further in the next section.

Personal Development Planning (PDP) is a highly appropriate vehicle for reflection and evaluation in this context and as all students are now entitled to PDP as part of their university experience it should be relatively straightforward to ensure that it is used to full effect in developing employability. The Higher Education Academy suggests that there is a strong link between PDP and employability and that:

\footnotetext{
"PDP can help students to
}

- plan, record and reflect upon their experiences in a way that develops their employment related skills and self-awareness;

- understand how their transferable skills might be applied in new settings; 
- make realistic and suitable career plans based upon their heightened selfknowledge;

- demonstrate both their employment potential and their ability to manage their future professional development to employers."

\section{Self-efficacy/Self-confidence/Self-esteem}

These three closely-linked 'Ss' of self-efficacy, self-confidence and self-esteem provide a crucial link between knowledge, understanding, skills, experience and personal attributes and employability.

According to Albert Bandura (1995, p. 2):

"Perceived self-efficacy refers to beliefs in one's capabilities to organize and execute the course of action required to manage prospective situations. Efficacy beliefs influence how people think, feel, motivate themselves and act."

Bandura (1995) suggests a number of sources of efficacy beliefs. The ones particularly relevant to employability are: mastery experiences, vicarious experiences provided by social models and social persuasion.

Mastery experiences occur when people are given the opportunity to try a particular task themselves. Examples of mastery experiences within the employability agenda are work experience, realistic work environments (as provided by the Centre for Employability Through the Humanities at UCLan, where students get the chance to 
be involved with activities such as publishing, theatre performances etc.), live student projects (where students work in a consultancy role to outside agencies) and some career development learning activities such as making job applications. According to Bandura (1995) mastery experiences are the most effective way of creating a strong sense of self-efficacy and so play a vital role within employability.

Vicarious experiences provided by social models occur when students are able to see others who have achieved success. The closer the others are in similarity to themselves, the more effective the experiences are. Examples of this are when successful recent graduates return to the university to give talks to current students about how they achieved their goals.

Social persuasion occurs when people are persuaded that they possess the capabilities needed to master a particular activity. This encourages them to put in more effort and stay motivated in order to achieve success in their goals. There is an important role for tutors to play here, particular in the way in which they provide feedback to their students. Bandura states that:

"A major goal of formal education should be to equip students with the intellectual tools, efficacy beliefs, and intrinsic interests to educate themselves throughout their lifetime." (1995, p. 17).

Therefore by providing the opportunities for mastery experiences, vicarious experiences and social persuasion, then encouraging reflection on and evaluation of these experiences, self-efficacy can be increased. A graduate who believes they can do whatever is necessary is far more likely to gain a position and be successful in whatever occupations they choose than a graduate who does not have that selfbelief. 
If self-efficacy is seen as a belief that one has the capability in a particular situation, then self-confidence could be seen as the way this is projected to the outside world. Self-confidence appears to be something that can be seen from a person's manner and behaviour. According to Goleman (1998, p. 68) people with self-confidence are able to present themselves with self-assurance and have 'presence'. It has been suggested that self-confidence can be either a trait or something that is specific to certain situations. Norman \& Hyland (2003) point out that if self-confidence is seen as a trait, which personality theorists suggest are relatively stable over time, then those who lack self-confidence would be unlikely to develop it through educational activity. If, however, it is viewed as a situationally specific concept, as is assumed by this new model, then it is possible for students to increase their levels of selfconfidence for any given situation. An increase in self-efficacy should be reflected in an increase in demonstrated self-confidence.

According to Owens (1993) people with global self-esteem have self-respect and a feeling of worthiness but are realistic in their evaluations of themselves. Without this realism a person is unlikely to reflect on areas for improvement, which is crucial to the process of lifelong learning. The USEM model (Knight \& Yorke, 2004) has ' $E$ ' (personal qualities including self-theories and efficacy beliefs) as something that colours everything the student and subsequent graduate does. It could also be suggested that everything the student does during their time at university, will impact on self-esteem and it is through the development of high global self-esteem that employability is achieved.

Lawrence (1996, p. xi) provides support for the inclusion of self-esteem in the model when he states that: 
"One of the most exciting discoveries in educational psychology in recent times has been the finding that people's levels of achievement are influenced by how they feel about themselves. A vast body of research evidence has accumulated showing a positive correlation between self-esteem and achievement..."

It is suggested that increased self-esteem is a major part of the key to employability. It is important to have a belief in one's ability to succeed and be able to project this belief to the outside world, but by achieving a high level of self-esteem a graduate will also be realistic about their achievements and be committed to lifelong learning. In the words of Gloria Steinem (1992, p. 26):

“...self-esteem isn't everything; it's just that there's nothing without it."

\section{Value of the Model}

Having discussed the components of the model and the justification for their inclusion, there is also a need to demonstrate how it will be a useful and practical addition to the literature already available on the subject of employability.

Firstly, any model of employability should inform the planning of programmes and structured interventions intending to focus on the area. This model provides clarity of information about what needs to be considered and included. Secondly, a model concerning graduate employability should be something that can be explained with ease to students and possibly their parents, as well as academics. This model allows lecturers, personal tutors, careers advisors or anybody else involved with the promotion of employability within Higher Education to do so without clouding the 
issue in complexity. Thirdly, the model will be a valuable tool for knowledge transfer activities. It can be used to demonstrate to employers how the roles of HEls and business can both contribute to graduate employability with the resultant benefits for both parties. Finally, it would be useful to have a model of employability that could be adapted for use with groups other than students and new graduates. It would be possible to adapt this model for use at any life stage, for example with mid-life career changers or people dealing with a redundancy situation.

\section{Future Developments}

Based on the 'Key to Employability' model, work has begun to develop a measurement tool with which students can evaluate their employability and identify any areas in which they need to access further opportunities for development. The intention is for this tool to be made available to practitioners also, to enable them to assess if their employability interventions are achieving their aims.

\section{Conclusion}

This article has introduced the 'Key to Employability' model, explained its components, justified their inclusion and discussed the value of the model. Employability is a lifelong issue and nobody is ever perfectly employable. There will always be aspects of a person's employability that would benefit from improvement. The model does not depict a process that a student embarks upon during their time in Higher Education and then graduates with employability for life. The issues within the model are likely to be revisited many times to ensure adaptability to the demands of a changing world and a better chance of occupational satisfaction and success. 


\section{References}

Bandura, A (1995), "Exercise of personal and collective efficacy in changing societies", in Bandura, A. (Ed.), Self-Efficacy in Changing Societies Cambridge University Press, Cambridge, pp $1-45$.

Bennett, N; Dunne, E \& Carré, C (1999), "Patterns of core and generic skill provision in higher education", Higher Education, Vol 37, pp 71 - 93.

Cooper, R K (1997), “Applying emotional intelligence in the workplace”, Training \& Development, Vol 51, No 12, pp 31 - 38.

Foster, D (2006), "Reflection of a Careers Adviser", Phoenix. The Journal of the Association of Graduate Careers Advisory Services, No 117 (Summer), pp 5-6.

Goleman, D (1998), Working with emotional intelligence, Bloomsbury, London

Graduate Prospects (2005/6), Prospects Directory Salary and Vacancy Survey, Graduate Market Trends, (Winter), pp $11-17$.

Harvey, L; Moon, S; Geall, V \& Bower, R (1997). Graduates' Work: Organisational change and students' attributes. Centre for Research into Quality, University of Central England, Birmingham. http://www.uce.ac.uk/crq/publications/gw/ [accessed 2 February 2007)

Hillage, J \& Pollard, E (1998), Employability: Developing a Frame work for Policy Analysis. Research Brief No 85. London, Department for Education and 
Employment. http://www.dfes.gov.uk/research/data/uploadfiles/RB85.doc [accessed 2 February 2007]

Hinchcliffe, R, (2001), Nice Work (If You Can Get It): Graduate Employability in the Arts and Humanities. The Developing Learning Organisations Project Consultation Document.

Higher Education Academy. Personal Development Planning. Available at http://www.heacademy.ac.uk/867.htm [accessed 13 February 2007]

Jaeger, A J (2003), “Job Competences and the Curriculum: An Inquiry into Emotional Intelligence in Graduate Professional Education", Research in Higher Education, Vol 44, No 6, pp 615-639.

Johnes, G (2006). Career interruptions and labour market outcomes. EOC Working Paper Series No 45. Equal Opportunities Commission, Manchester.

Knight, P \& Yorke, M (2004), Learning, Curriculum and Employability in Higher Education, RoutledgeFalmer, London.

Law, W \& Watts, A G (1977), Schools, Careers and Community, Church Information Office, London.

Lawrence, D (1996), Enhancing Self-Esteem in the Classroom, $2^{\text {nd }}$ Edition, Paul Chapman Publishing Ltd, London. 
Mayer, J D; Salovey, P \& Caruso, D R (2004), "Emotional Intelligence: Theory, Findings, and Implications". Psychological Inquiry, Vol 15, No 3, pp 197 - 215.

McCash, P (2006), "We're all career researchers now: breaking open career education and DOTS." British Journal of Guidance and Counselling, Vol 34, No 4, November, pp 430-449

Moon, J (2004), Reflection and employability. The Higher Education Academy, York.

Moynagh, M \& Worsley, R (2006). Glimpses of tomorrow. The Tomorrow Project. http://www.tomorrowproject.net/pub/1 GLIMPSES/Employment/-237.html

[Accessed 2 February 2007]

Norman, M \& Hyland, T (2003), "The Role of Confidence in Lifelong Learning", Educational Studies, Vol 29 , No 2/3, pp $261-272$.

Owens, T J (1993), "Accentuate the Positive - and the Negative: Rethinking the use of Self-Esteem, Self-Deprecation, and Self-Confidence", Social Psychology Quarterly, Vol 56, No 4, pp 288 - 299.

Qualter, P; Whiteley, H E \& Gardner, K (2007), "Emotional Intelligence: Review of Research and Educational Implications", Pastoral Care in Education, March 2007, pp $11-20$

Steinem, G (1992), Revolution from Within. A Book of Self-Esteem, Little Brown \& Company, Boston.

The Pedagogy for Employability Group (2004), "Pedagogy for Employability", 
Available

http://www.heacademy.ac.uk/resources.asp?process=full record\&section=generic\&i

$\underline{\mathrm{d}=510}$ [accessed 2 February 2006].

Tucker, M L; Sojka, J Z; Barone, F J \& McCarthy, A M (2000), "Training Tomorrow's Leaders: Enhancing the Emotional Intelligence of Business Graduates", Journal of Education for Business, Vol 75, No 6, pp 331 - 338.

Watts, A G (2006). Career development learning and employability. The Higher Education Academy, York.

Work Experience Group (2002). Work Related Learning Report. DFES Publications, Nottingham.

Yorke, M \& Knight, P (2002), Employability through the curriculum. Skills Plus: Tuning the Undergraduate Curriculum. June 2002 edition.

Yorke, M \& Knight, P T (2004). Embedding Employability into the Curriculum. Higher Education Academy, York.

\section{Acknowledgments}

Our thanks to Lionel Bunting for his helpful suggestions with the visual presentation of the model. 